\title{
Phellinsin A, a Novel Chitin Synthases Inhibitor Produced by Phellinus sp. PL3
}

\author{
Eut-Il Hwang, Bong-SiK Yun, Young-KoOK KIM"a, \\ Byoung-Mog Kwon, Hong-Gi KIM ${ }^{\mathrm{b}}$, HyAng-BoK LEE, \\ WON-JIN JEONG ${ }^{c}$ and SUNG-UK KIM*

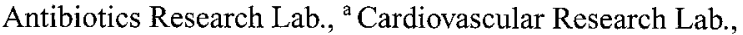 \\ and ${ }^{\mathrm{c}}$ Korean Collection for Type Cultures, \\ Korea Research Institute of Bioscience \& Biotechnology, \\ P. O. Box 115, Yusung, Taejon 305-333, Korea \\ ${ }^{\mathrm{b}}$ Division of Applied Biology, Chemistry and Food Science, \\ Chungnam National University, \\ Yusung, Taejon 305-764, Korea
}

(Received for publication December 27, 1999)

\begin{abstract}
Phellinsin A, a novel chitin synthases inhibitor was isolated from the cultured broth of fungus PL3, which was identified as Phellinus sp. PL3. Phellinsin A was purified by solvent partition, silica gel, ODS column chromatographies, and preparative HPLC, consecutively. The structure of phellinsin A was assigned as a phenolic compound on the basis of various spectroscopic analyses including UV, IR, Mass, and NMR. Its molecular weight and formula were found to be 358 and $\mathrm{C}_{18} \mathrm{H}_{14} \mathrm{O}_{8}$, respectively. Phellinsin A selectively inhibited chitin synthase I and II of Saccharomyces cerevisiae with an $\mathrm{IC}_{50}$ value of 76 and $28 \mu \mathrm{g} / \mathrm{ml}$, respectively, in our cell free assay system. This compound showed antifungal activity against Colletotrichum lagenarium, Pyricularia oryzae, Rhizoctonia solani, Aspergillus fumigatus, and Trichophyton mentagrophytes.
\end{abstract}

Chitin is a structural polymer present in most fungal cell walls. Although its amount varies from $1 \sim 30 \%$ of the cell wall, it have been shown to be indispensable for the maintenance of the fungal cell ${ }^{1}$. Mutations that affect chitin synthesis cause osmotic sensitivity ${ }^{2,3)}$, abnormal morphology, aggregation, and growth arrest with elongated buds ${ }^{4,5)}$.

There are three different chitin synthases in Saccharomyces cerevisiae: chitin synthase I is nonessential repair enzyme of damaged chitin ${ }^{6,7)}$; chitin synthase II is an essential enzyme for primary septum formation between mother and daughter cells ${ }^{5,8 \sim 10)}$; chitin synthase III makes $90 \sim 95 \%$ of the cellular chitin, including the chitin synthesized during mating and spoluration ${ }^{5}$. Therefore, specific inhibitors of chitin synthase II and III might be interesting lead compounds to develop effective antifungal agents.

As a part of our continuing efforts to discover naturally occurring new antifungal agents, we have screened for chitin synthase II inhibitors of microbial origin. We report herein on the taxonomy and fermentation of the phellinsin
A-producing strain and structural elucidation, physicochemical properties and biological activity of a novel antifungal metabolite, phellinsin A (Fig. 1).

\section{Materials and Methods}

\section{Phellinsin A-producing Strain}

The phellinsin A-producing mushroom, strain PL3, was collected from the trunk of Morus alba at Mountain

Fig. 1. Structure of phellinsin A.

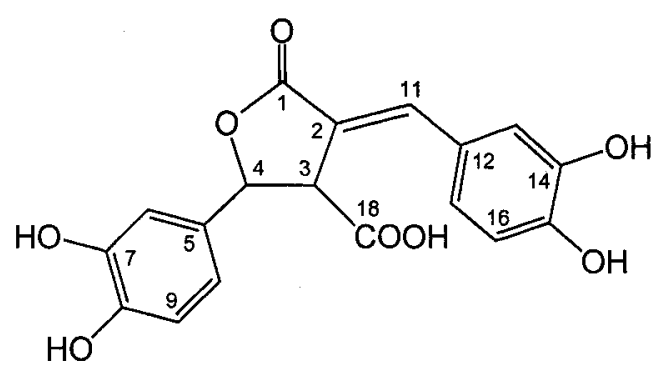


Kyeryong, Chungcheongnam province, Korea. Chemical reaction of basidiospores was tested according to GILBERTSON and RYVARDEN ${ }^{11)}$. Microscopical structures of hypae and basidiospores were observed using $4 \% \mathrm{KOH}$ solution, Cotton-blue solution or Melzer's reagent as mouting solutions. For the evaluation of cultural characteristics, the strain was grown on CYA (yeast extract $0.5 \%, \mathrm{NaNO}_{3} 0.3 \%, \mathrm{~K}_{2} \mathrm{HPO}_{4} 0.1 \%, \mathrm{MgSO}_{4} \cdot 7 \mathrm{H}_{2} \mathrm{O} \quad 0.05 \%$, $\mathrm{KCl} 0.05 \%, \mathrm{FeSO}_{4} \cdot 7 \mathrm{H}_{2} \mathrm{O} 0.001 \%, \mathrm{CuSO}_{4} \cdot 5 \mathrm{H}_{2} \mathrm{O} 0.0005 \%$, $\mathrm{ZnCl}_{2} \cdot 7 \mathrm{H}_{2} \mathrm{O} 0.001 \%$, sucrose $3.0 \%$, agar $1.5 \%$ ), CYA20S (CYA medium with sucrose increased to $20 \%$ ), Czapek dox agar $\left(\mathrm{NaNO}_{3} \quad 0.3 \%, \mathrm{~K}_{2} \mathrm{HPO}_{4} 0.1 \%, \mathrm{MgSO}_{4} \cdot 7 \mathrm{H}_{2} \mathrm{O} \quad 0.05 \%\right.$, $\mathrm{KCl} 0.05 \%, \mathrm{FeSO}_{4} \cdot 7 \mathrm{H}_{2} \mathrm{O} 0.001 \%$, sucrose $3.0 \%$, agar $1.5 \%$ ), MEA (malt extract $2.5 \%$, agar $1.5 \%$ ), PDA (Difco Co.), YMA (yeast extract $0.3 \%$, malt extract $0.3 \%$, tryptone $0.5 \%$, agar $1.5 \%$ ) media, for 14 days at $25^{\circ} \mathrm{C}$ to $42^{\circ} \mathrm{C}$. Morphological observation was carried out using a light microscope (Nikon, EFD3). The color names used were based on the ISCC-NBC Color-Name Chart Illustrated with Centroid Colors.

\section{Fermentation}

One frozen stock vial ( $1 \mathrm{ml}$ of spore suspension in $10 \%$ glycerol, $-80^{\circ} \mathrm{C}$ ) of strain PL3 was inoculated into a $500 \mathrm{ml}$ baffled-flask containing seed medium(glucose $0.5 \%$, soluble starch $1.5 \%$, yeast extract $0.2 \%$, polypeptone $0.5 \%$, $\mathrm{KH}_{2} \mathrm{PO}_{4} 0.1 \%$ and $\mathrm{MgSO}_{4} \cdot 7 \mathrm{H}_{2} \mathrm{O} 0.05 \%, \mathrm{pH} 5.8$ prior to autoclaving). Distilled water was used in preparation of seed and production media. The seed culture was incubated for 4 days at $26^{\circ} \mathrm{C}$ on a rotary shaker at $150 \mathrm{rpm}$ (radius $7 \mathrm{~cm}$ ). Twenty $\mathrm{ml}$ of the seed culture was transferred into a 5-liter baffled-flask containing 1 liter of production medium (Potato dextrose broth; Difco Co.). The fermentation was carried out for 5 days at $26^{\circ} \mathrm{C}$ on a rotary shaker at $150 \mathrm{rpm}$. To determine the cell mass, mycelia were collected by filtration using Whatman No. 2 filter paper, then washed twice with distilled water and oven dried at $105^{\circ} \mathrm{C}$ to a constant weight.

\section{Spectral Analysis}

The UV spectrum was recorded on a Shimadzu UV265 UV-Visible spectrophotometer. The $\mathrm{pH}$ was measured with an Orion research digital $\mathrm{pH} /$ millivolt meter 611 and Ross electrode. ESI mass spectrum was recorded on a Hewlett Packard 5989A. ${ }^{1} \mathrm{H}$ - and ${ }^{13} \mathrm{C}-\mathrm{NMR}$ spectra were obtained on a Varian UNITY 500 spectrometer using $\mathrm{CD}_{3} \mathrm{OD}$. Chemical shifts are given in ppm using TMS as internal standard.
Chitin Synthases Assay

Saccharomyces cerevisiae YPH499 (ura3-52 lys2-

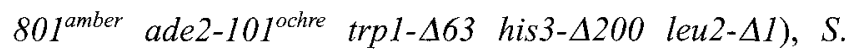
cerevisiae ECY38-38A (MATa chs1-23 chs2::LEU2 call/csd2 ura3-52 trp1-1 leu2-2 pAS6), and S. cerevisiae ECY38-38A (MATa chs1-23 chs2::LEU2 call/csd2 ura352 trp 1-1 leu2-2 pWJC6) were used as sources of chitin synthase I, II, and III activity, respectively. S. cerevisiae YPH499 is wild type for all three synthases and grown in YEPD (yeast extract $1 \%$, peptone $2 \%$, glucose $2 \%$ ). $S$. cerevisiae ECY38-38A (pAS6) and S. cerevisiae ECY3838A (pWJC6), which can only overexpress the chitin synthase II and III, respectively, when grown in YPG (yeast extract $1 \%$, peptone $2 \%$, galactose $2 \%$ ).

Cells suspended in $50 \mathrm{~mm}$ Tris- $\mathrm{HCl}(\mathrm{pH} 7.5)$ containing $5 \mathrm{~mm}$ magnesium acetate were broken by vortex mixing with glass beads ${ }^{12)}$. Cell walls were sedimented at $4,000 \times g$ for 5 minutes and the supernatant fluid was centrifuged at $130,000 \times g$ for 45 minutes. The membrane pellet was suspended in the $50 \mathrm{~mm}$ Tris- $\mathrm{HCl}$ (pH 7.5) containing 33\% glycerol used in the breakage, to a final volume of $1.6 \mathrm{ml} / \mathrm{g}$ (wet weight) of cells. Chitin synthase II activity was measured by the described procedure ${ }^{12)}$. For the proteolytic activation step, reaction mixtures contained $32 \mathrm{mM}$ Tris$\mathrm{HCl}(\mathrm{pH} 7.5), 1.6 \mathrm{mM}$ cobalt acetate, $1.0 \mathrm{mM} \mathrm{UDP}-\left[{ }^{14} \mathrm{C}\right]-\mathrm{N}$ acetylglucosamine $(400,000 \mathrm{cpm} / \mu \mathrm{mol}, \mathrm{NEN}), 2 \mu \mathrm{l}$ of trypsin at the optimal concentration for activation $(2.0 \mathrm{mg} / \mathrm{ml}), 20 \mu \mathrm{l}$ of membranes, and $14 \mu \mathrm{l}$ of the test sample in a total volume of $46 \mu \mathrm{l}$. The mixtures were preincubated for 15 minutes at $30^{\circ} \mathrm{C}$. Proteolysis was stopped by adding $2 \mu 1$ of a soybean trypsin inhibitor solution $(4.0 \mathrm{mg} / \mathrm{ml})$ at a concentration 2 times that of trypsin solution used, and tubes were placed on ice for 10 minutes. GlcNAc was added to a final concentration of $32 \mathrm{mM}$ and incubation at $30^{\circ} \mathrm{C}$ was carried out for 90 minutes. For chitin synthase III activity ${ }^{12)}$, the assay was performed the same as that for chitin synthase II except that $32 \mathrm{mM}$ Tris- $\mathrm{HCl}(\mathrm{pH} 7.5)$ and $4.3 \mathrm{~mm}$ magnesium acetate were used. For chitin synthase I activity ${ }^{12)}$, reaction mixtures contained $37 \mathrm{mM}$ Tris- $\mathrm{HCl}(\mathrm{pH} 7.5), 0.12 \%$ digitonin, $4.8 \mathrm{mM}$ magnesium acetate, $2 \mu \mathrm{l}$ of trypsin $(1.0 \mathrm{mg} / \mathrm{ml}), 6 \mu \mathrm{l}$ of membrane suspension, and $14 \mu \mathrm{l}$ of the test sample in a total volume of $41 \mu 1$. After 15 minutes of incubation at $30^{\circ} \mathrm{C}, 2 \mu \mathrm{l}$ of trypsin inhibitor $(2.0 \mathrm{mg} / \mathrm{ml})$ was added, and the tubes were placed on ice. $32 \mathrm{~mm}$ GlcNAc and $1.0 \mathrm{~mm}$ UDP- $\left[{ }^{14} \mathrm{C}\right]$-GlcNAc were added as for the chitin synthase II and III assay, and the mixtures were incubated for 30 minutes at $30^{\circ} \mathrm{C}$. In all cases, the reaction was stopped by the addition of $10 \%$ trichloroacetic acid and the radioactivity of the insoluble chitin formed was counted 
after filtration through glass fiber filters (GF/C, Whatman). The concentration of protein was measured by the method of LowRY ${ }^{13)}$. Blank values were measured with addition of $25 \%$ aqueous $\mathrm{MeOH}$ instead of both enzyme and test sample. Percent inhibition of chitin synthase activity was calculated by subtracting the blank values from both control and test sample values.

$$
\% \text { Inhibition }=\left[1-\frac{\text { Sample }(\mathrm{cpm})-\text { Blank }(\mathrm{cpm})}{\text { Control }(\mathrm{cpm})-\text { Blank }(\mathrm{cpm})}\right] \times 100
$$

The chitin synthase II and III activities of the enzyme were confirmed using positive controls polyoxin $\mathrm{D}$ and nikkomycin Z (Calbiochem. Co.), respectively.

Fig. 2. The fruiting body of Phellinus sp. PL3.

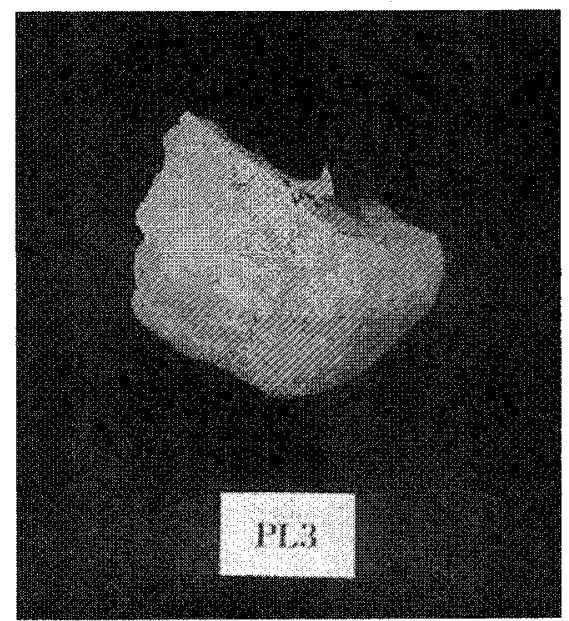

\section{Antifungal Activity}

Minimum inhibitory concentrations (MIC) were determined by the two-fold serial agar dilution method. Human pathogenic fungi were grown on Sabouraud's agar medium, and plant pathogenic fungi were grown on potato dextrose agar medium. Antifungal activity was observed after 24 -hour incubation at $30^{\circ} \mathrm{C}$ for yeasts and 48 -hour incubation for fungi at $25^{\circ} \mathrm{C}$.

\section{Results}

Taxonomic Studies of the Producing Organism

The fruiting body of strain PL3 was corky, yellowish brown, and sessile (Fig. 2). Basidiospores were subglobose to ellipsoidal in shape. They were hyaline in young ones, became yellowish-brown with age, and $4.0 \sim 5.7 \times 3.0 \sim$ $4.7 \mu \mathrm{m}$ in size. They showed weakly cyanophilic and nondextrinoid reaction in Cotton-blue solution and Melzer's reagent, respectively. Hyphal structures of trama were dimitic with generative and skeletal hyphae. Hymenial setae were abundantly found and $27 \sim 57 \times 5.7 \sim 9.3 \mu \mathrm{m}$ in size. Pores were formed in $7 \sim 9$ per $\mathrm{mm}$ on hymenial layer. Setal hyphae were not found.

The cultural characteristics of strain PL3 after incubation on six agar media at $25^{\circ} \mathrm{C}$ to $42^{\circ} \mathrm{C}$ for 14 days are summarized in Table 1. The optimal temperature for growth of the fungus PL 3 was at $30^{\circ} \mathrm{C}$ with little growth observed at $42^{\circ} \mathrm{C}$. The mycelium was pale orange to yellow brown and the reverse side was pale orange yellow to dark brown in color. The simple septa without clamp-connection was also observed in hyphae like other Phellinus $\mathrm{sp}^{14)}$.

Table 1. Cultural characteristics of fungus PL3 on several media.

\begin{tabular}{|c|c|c|c|c|c|c|}
\hline \multirow{2}{*}{ Media } & \multicolumn{4}{|c|}{ Colony size $(\mathrm{mm}))^{\mathrm{a} /{ }^{\circ} \mathrm{C}}$} & \multirow{2}{*}{ Color of mycelium ${ }^{b}$} & \multirow{2}{*}{ Color of reverse side } \\
\hline & 125 & 130 & 137 & 142 & & \\
\hline CYA & 45 & 52 & 33 & 7 & Pale orange yellow & Pale orange yellow \\
\hline CYA20S & 47 & 53 & 42 & 8 & Pale yellow & Pale orange yellow \\
\hline Czapek & 48 & 58 & 34 & 7 & Pale orange yellow & Pale orange yellow \\
\hline MEA & 85 & 85 & 40 & 7 & Vivid yellow & Dark yellow \\
\hline PDA & 85 & 85 & 45 & 7 & Vivid yellow & Dark orange yellow \\
\hline YMA & 71 & 85 & 37 & 7 & Strong yellowish brown & Dark brown \\
\hline
\end{tabular}

${ }^{\mathrm{a} C}$ Colony size measured after 14 days.

bISCC-NBS color-name chart illustrated with centroid colors, U. S. Dept. of Comm. Suppl. to

NBS Circular 533, Washington, D. C., 1985 
Fig. 3. Time course of phellinsin A production by Phellinus sp. PL3.

Phellinus sp. PL 3 was cultivated at $26^{\circ} \mathrm{C}$ in $50 \mathrm{ml}$ potato dextrose broth medium.

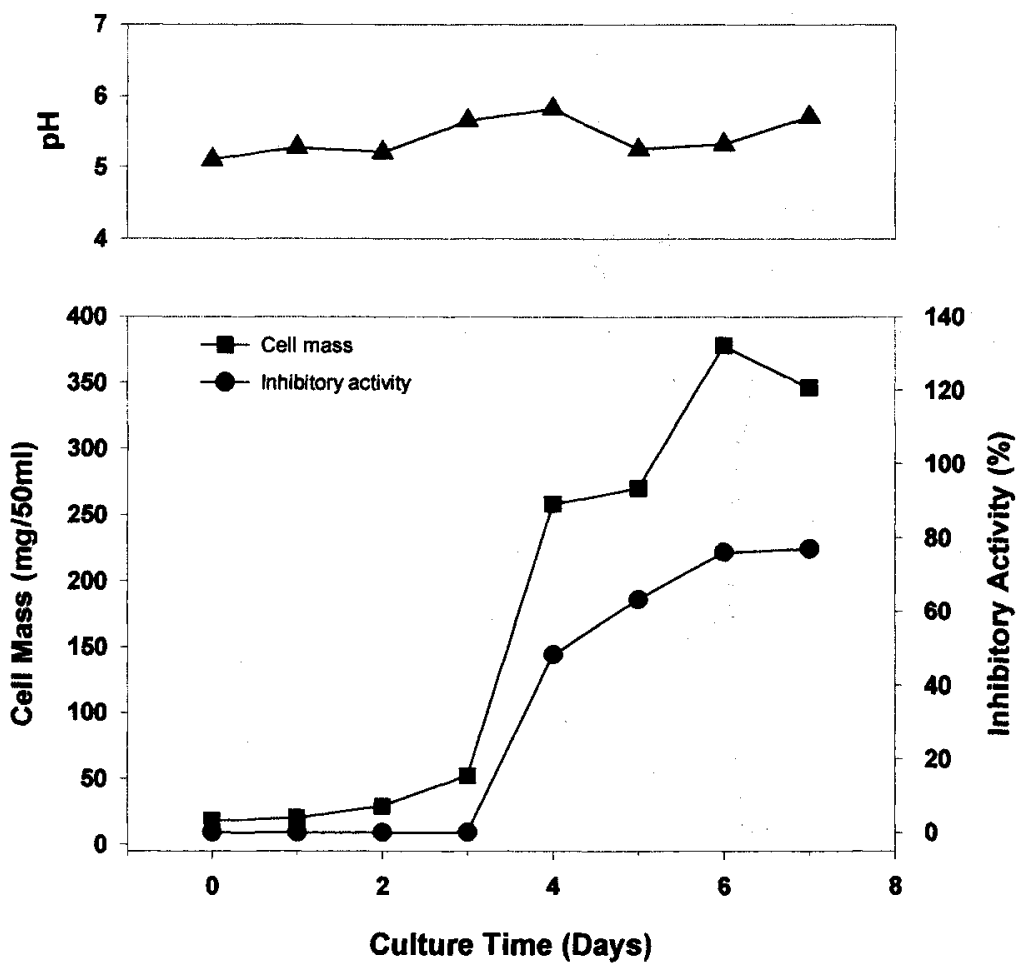

Based on the morphological and biochemical characteristics, strain PL3 was classified into Phellinus species owing to abundant hymenial setae, blackening of their basidiocarps to $\mathrm{KOH}$ treatment, and dimitic hyphal structures $^{15)}$. The combination of morphological and biochemical characteristics of basidiospores, setae, basidiocarps and host specificity led to the conclusion that strain PL3 is closely related to $P$. linteus, $P$. johnsonianus or $P$. baumii, which belong to LARSEN and COBB's Group $\mathrm{III}^{16)}$. However, strain PL3 is slightly different from the above three species. $P$. johnsonianus has been reported to be resupinate to reflexed in the morphology of basidiocarps, while strain PL3 is distinctly sessile ${ }^{17}$. Strain PL3 was consistent with description on $P$. baumii according to DAI and $\mathrm{XU}^{18)}$, concerning the thickness in $\mathrm{KOH}$ solution of tramal skeletal hyphae. Tramal skeletal hyphae were $2.3 \sim 4.8 \mu \mathrm{m}$ thick in strain PL3, 2.5 3.5 $\mu \mathrm{m}$ in $P$. baumii and $3.9 \sim 6.0 \mu \mathrm{m}$ in $P$. linteus. However, this strain had a little larger basidiospores than of $P$. baumii $(3.3 \sim 4.5 \times$ $2.4 \sim 3.5 \mu \mathrm{m}$ ) according to DAI and XU descriptions ${ }^{18)}$. Size of basidiospores in strain PL3 $(4.3 \sim 5.5 \times 3.8 \sim 4.8 \mu \mathrm{m})$ was similar to that of $P$. linteus. In addition, the contextural skeletal hyphae were thinner than those of $P$. linteus and $P$. baumii. The contextural skeletal hyphae in $\mathrm{KOH}$ solution were $2.4 \sim 4.1 \mu \mathrm{m}$ thick in strain PL3, while $4.5 \sim 6.1 \mu \mathrm{m}$ and $4.8 \sim 7.0 \mu \mathrm{m}$ in $P$. linteus and $P$. baumii, respectively. In conclusion, strain PL3 seems to be a relative but a distinctly different species of the three Phellinus species. Therefore, this fungus was designated as Phellinus sp. PL3. It was deposited in the Korean Collection for Type Culture (KCTC) as KCTC 0613BP.

\section{Fermentation}

The fermentation was followed by monitoring for chitin synthase II inhibitory activity. A typical time course production of phellinsin A in a $500 \mathrm{ml}$ baffled Erlenmeyer flask fermentation is shown in Fig. 3. The inhibitory activity for chitin synthase II started after 3 days and reached a maximum after 6 days of cultivation. Cell mass also reached a maximum after 6 days of fermentation. 
Fig. 4. Purification steps for phellinsin A.

\author{
Fermentation broth of Phellinus sp. PL3 (10L) \\ Filtered with Whatman No.2 \\ Broth filtrate \\ Extracted with EtOAc \\ EtOAc extract \\ $\mid$ \\ Silica gel column chromatography \\ $\mathrm{CHCl}_{3}: \mathrm{MeOH}, 9: 1(\mathrm{v} / \mathrm{v})$ \\ $\mathrm{C}_{18}$ column chromatography \\ $40-50 \%$ aqueous $\mathrm{MeOH}$ \\ Preparative silica gel TLC \\ $\mathrm{CHCl}_{3}: \mathrm{MeOH}$ :Acetone, 36:4:1 (in volumn) \\ HPLC \\ Eluted with $20 \%$ aqueous $\mathrm{MeOH}$ \\ Phellinsin A(6mg)
}

Isolation

The isolation procedure for phellinsin $\mathrm{A}$ is shown in Fig 4. A five-day old fermentation broth of Phellinus sp. PL3 (10 liters) was filtered with Whatman No. 2 filter paper. The broth was extracted twice with 10 liters of ethyl acetate and the ethyl acetate layers were evaporated in vacuo. The residue was applied to a column of silica gel (Merck, Kieselgel 60, 230 400 mesh) and the column was eluted with chloroform-methanol, 9:1 (v/v), to give a yellow brown residue, which inhibited chitin synthase II by $60 \sim 70 \%$ at $280 \mu \mathrm{g} / \mathrm{ml}$. The residue was purified with an ODS column (Merck, Lichroprep RP-18, 40 63 $\mu \mathrm{m}$ ) eluted with a gradient of water-methanol (4:1 to $100 \%$ methanol, v/v) and then the yellow residue was found in $40 \sim 50 \%$ aqueous methanol fractions, which inhibited chitin synthase II by $70 \%$ at $280 \mu \mathrm{g} / \mathrm{ml}$. The residue was further purified on preparative silica gel TLC developed with chloroform - methanol - isopropyl alcohol, 36:4:1 (in volume). The active zone ( $\operatorname{Rf} 0.15$ ) was extracted with methanol and the resulting solution was concentrated in vacuo to yield a yellow material. Finally, the material was dissolved in methanol and subjected to preparative HPLC using an ODS column (YMC-Park, C18 SH-343-5, No $204788(\mathrm{~W})$ ). The column was eluted with a mixture of methanol-water, $2: 8(\mathrm{v} / \mathrm{v})$ at a flow rate of $2 \mathrm{ml} / \mathrm{minute}$. An active substance was eluted as a peak with retention time of 30 minutes and detected by a UV spectrophotometric detecter $(213 \mathrm{~nm})$. The substance was collected and concentrated in vacuo to give a yellow powder of pure phellinsin $\mathrm{A}(6 \mathrm{mg})$.

\section{Physico-chemical Properties and Structure}

The physico-chemical properties of phellinsin $\mathrm{A}$ are summarized in Table 2. Phellinsin A was obtained as yellow power and showed a $\mathrm{Rf}$ value of 0.5 in $\mathrm{MeOH}-\mathrm{H}_{2} \mathrm{O}$, $2: 8(\mathrm{v} / \mathrm{v})$, on a Merck RP-18 TLC plate. Phellinsin A was soluble in $\mathrm{MeOH}, \mathrm{DMSO}$ and distilled water but insoluble in $\mathrm{CHCl}_{3}$ and $n$-hexane. The molecular formula was determined to be $\mathrm{C}_{18} \mathrm{H}_{14} \mathrm{O}_{8}$ on the basis of the ESI-MS spectrum in combination with ${ }^{1} \mathrm{H}$ - and ${ }^{13} \mathrm{C}$-NMR spectral data (Table 3). The IR spectrum suggested the presence of hydroxyl groups $\left(3400 \mathrm{~cm}^{-1}\right)$ and carbonyl groups $(1718 \sim$ $1737 \mathrm{~cm}^{-1}$ ).

The structure determination of phellinsin A was carried out by NMR spectroscopic analyses. The ${ }^{1} \mathrm{H}-\mathrm{NMR}$ spectrum of phellinsin A showed two $A M X$ spin systems due to two 1,3,4-trisubstituted benzenes $(6.65,6.71,6.74$ ppm and $6.80,7.03,7.13 \mathrm{ppm}$ ) in the aromatic region, and three methine proton peaks at 4.01, 5.59 and $7.51 \mathrm{ppm}$.

In the ${ }^{13} \mathrm{C}-\mathrm{NMR}$ spectrum, all eighteen carbons were observed. The DEPT experiment revealed the presence of nine quaternary and nine methine carbons, and a HMQC experiment established all direct ${ }^{1} \mathrm{H}^{13}{ }^{13} \mathrm{C}$ connectivities. The ${ }^{1} \mathrm{H}$ - and ${ }^{13} \mathrm{C}$-NMR spectral data of phellinsin $\mathrm{A}$ are shown in Table 3. The ${ }^{1} \mathrm{H}-{ }^{1} \mathrm{H}$ COSY spectrum revealed the three partial structures indicated in Fig. 5 including allylic coupling between $\mathrm{H}-3$ (4.01 ppm) and $\mathrm{H}-11$ (7.51 ppm). These partial structures were further connected with HMBC data, which showed long-range correlations from the methine proton at $7.51 \mathrm{ppm}$ to two aromatic carbons at 118.1 and $125.5 \mathrm{ppm}$, and from an oxygenated methine proton at $5.59 \mathrm{ppm}$ to two aromatic carbons at 113.4 and $118.3 \mathrm{ppm}$, assigning the attached positions of two benzene rings. The $\gamma$-lactone moiety was unambiguously assigned by the long-range couplings from the methine proton at $5.59 \mathrm{ppm}$ to $s p^{2}$ quaternary carbons at 174.8 and $121.6 \mathrm{ppm}$. In addition, correlations between the proton at $7.51 \mathrm{ppm}$ and carbons at 174.8 and $56.7 \mathrm{ppm}$ completed the structure of phellinsin $A$ as shown in Fig 5. The regiostereochemistry of olefin carbon (C-11) was determined to be trans by the NOE effect observed between the methine 
Table 2. Physico-chemical properties of phellinsin A.

\begin{tabular}{|c|c|}
\hline Properties & Phellinsin A \\
\hline Appearance & Yellow powder \\
\hline \multicolumn{2}{|l|}{ ESI-MS $(m / z)$} \\
\hline positive mode & $358.9[\mathrm{M}+\mathrm{H}]^{+}$ \\
\hline negative mode & $356.9[\mathrm{M}-\mathrm{H}]^{+}$ \\
\hline Molecular formula & $\mathrm{C}_{18} \mathrm{H}_{14} \mathrm{O}_{8}$ \\
\hline$[a]_{\mathrm{D}}^{25}$ & $0(\mathrm{c} 0.03 \mathrm{MeOH})$ \\
\hline UV $\lambda_{\max }{ }^{\mathrm{MeOH}} \operatorname{nm}(\log \varepsilon)$ & $336(3.79), 205(4.20)$ \\
\hline IR $v \mathrm{~cm}^{-1}(\mathrm{KBr}$, disk $)$ & $3400,2922,2852,1737,1718$ \\
\hline Rf value ${ }^{a}$ & 0.5 \\
\hline Soluble & $\mathrm{MeOH}, \mathrm{DMSO}, \mathrm{H}_{2} \mathrm{O}$ \\
\hline \multirow[t]{2}{*}{ Insoluble } & $\mathrm{CHCl}_{3}, n$-hexane, $\mathrm{CH}_{2} \mathrm{Cl}_{2}, \mathrm{EtOH}$, \\
\hline & EtOAc, $\mathrm{CH}_{3} \mathrm{CN}, i$-PrOH, Acetone \\
\hline
\end{tabular}

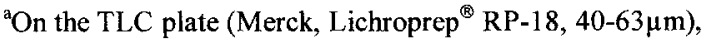
$\mathrm{MeOH}: \mathrm{H}_{2} \mathrm{O}(2: 8, \mathrm{v} / \mathrm{v})$.

Table 3. ${ }^{1} \mathrm{H}$ - and ${ }^{13} \mathrm{C}-\mathrm{NMR}$ spectral data of phellinsin A.

\begin{tabular}{clc}
\hline No & ${ }^{1} \mathrm{H}-\mathrm{NMR}\left(\delta_{\mathrm{H},}, J=\mathrm{Hz}\right)$ & ${ }^{13} \mathrm{C}-\mathrm{NMR}\left(\delta_{\mathrm{C},} \mathrm{ppm}\right)$ \\
\hline 1 & & 174.8 \\
2 & & 121.6 \\
3 & $4.01(1 \mathrm{H}, \mathrm{t}, 2.2)$ & 56.7 \\
4 & $5.59(1 \mathrm{H}, \mathrm{d}, 2.5)$ & 83.7 \\
5 & & 133.3 \\
6 & $6.74(1 \mathrm{H}, \mathrm{d}, 8.3)$ & 113.4 \\
7 & & 146.8 \\
8 & & 146.9 \\
9 & $6.71(1 \mathrm{H}, \mathrm{d}, 2.0)$ & 116.5 \\
10 & $6.65(1 \mathrm{H}, \mathrm{dd}, 8.3,2.0)$ & 118.3 \\
11 & $7.51(1 \mathrm{H}, \mathrm{d}, 2.0)$ & 140.9 \\
12 & & 127.2 \\
13 & $7.13(1 \mathrm{H}, \mathrm{d}, 2.2)$ & 118.1 \\
14 & & 146.6 \\
15 & & 149.6 \\
16 & $6.80(1 \mathrm{H}, \mathrm{d}, 8.3)$ & 116.6 \\
17 & $7.03(1 \mathrm{H}, \mathrm{dd}, 8.3,2.2)$ & 125.5 \\
18 & & 176.0 \\
\hline
\end{tabular}

- Measured in $\mathrm{CD}_{3} \mathrm{OD}$. $\mathrm{s}$; singlet, $\mathrm{d}$; doublet, $\mathrm{t}$; triplet, $\mathrm{dd}$; doublet of doublets.

proton at $4.01 \mathrm{ppm}$ and two aromatic protons at 7.03 and $7.13 \mathrm{ppm}$. Stereochemistries of chiral carbons at $83.7(\mathrm{C}-4)$ and $56.7 \mathrm{ppm}(\mathrm{C}-3)$ remain to be established.
Fig. 5. ${ }^{1} \mathrm{H}-{ }^{1} \mathrm{H}$ COSY, HMBC, and NOE experiments of phellinsin $\mathrm{A}\left(\mathrm{CD}_{3} \mathrm{OD}\right)$.

Arrows are directing $\mathrm{H}$ to $\mathrm{C}$.

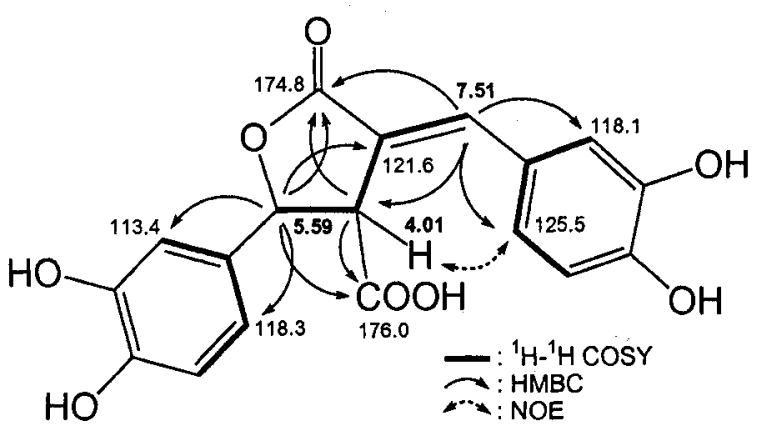

Biological Activity

Inhibition of Chitin Synthases by Phellinsin A

Phellinsin A inhibited chitin synthase I and II in a dosedependent manner at concentrations up to $280 \mu \mathrm{g} / \mathrm{ml}$ (Fig. 6). The $\mathrm{IC}_{50}$ value of phellinsin $\mathrm{A}$ for chitin synthase $\mathrm{I}$ and II were 76 and $28 \mu \mathrm{g} / \mathrm{ml}$, respectively. These results suggest that phellinsin $\mathrm{A}$ is 2.5 times stronger inhibitory activity than that of the previously identified chitin synthases inhibitor, polyoxin $\mathrm{D}\left(\mathrm{IC}_{50}, 70 \mu \mathrm{g} / \mathrm{ml}\right)^{19,29)}$, whereas it exhibited very weak inhibitory activity against chitin synthase $\mathrm{I}$ as compared with polyoxin $\mathrm{D}\left(\mathrm{IC}_{50}\right.$, 
$\leq 5.2 \mu \mathrm{g} / \mathrm{ml}^{19}{ }^{19}$. Phellinsin A did not exhibit inhibitory activity against chitin synthase III from $S$. cerevisiae ECY38-38A (pWJC6) (Data not shown).

\section{Antifungal Activity}

Phellinsin A exhibited antifungal activity against human fungal pathogens such as Trichophyton mentagrophytes and Aspergillus fumigatus with MIC value of $50 \mu \mathrm{g} / \mathrm{ml}$, but

Fig. 6. Inhibition of chitin synthase II by phellinsin $\mathrm{A}$.

-, Chitin synthase I; $O$, Chitin synthase II.

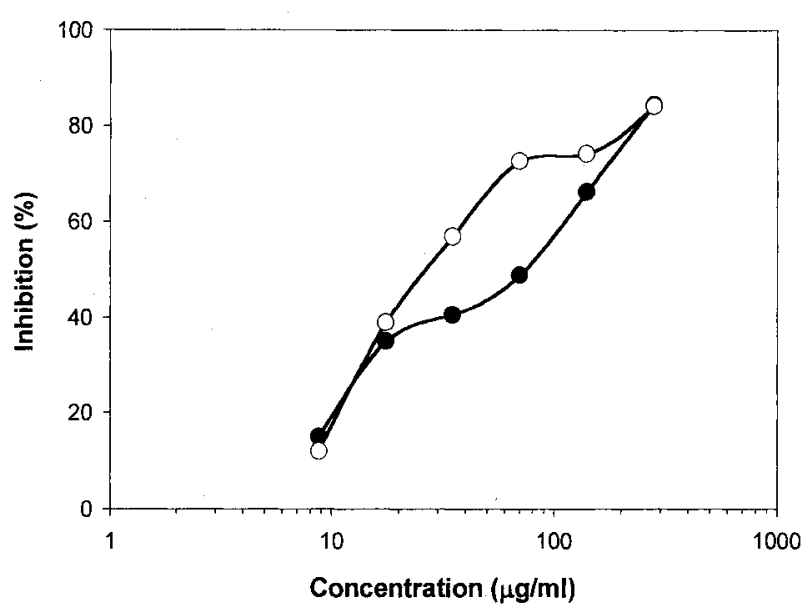

very weak activity against other human fungal pathogens, such as Cryptococcus neoformans and Coccidioides immitis (MIC, $100 \mu \mathrm{g} / \mathrm{ml}$ ) (Table 4). This compound also exhibited strong antifungal activity against the plant pathogens Colletotrichum lagenarium, Pyricularia oryzae, and Rhizoctonia solani with MICs of 12.5 and $50 \mu \mathrm{g} / \mathrm{ml}$, respectively. It showed no activity against Candida albicans, C. lusitaniae, C. krusei, C. tropicalis and Fusarium oxysporum at a concentrations up to $100 \mu \mathrm{g} / \mathrm{ml}$.

\section{Discussion}

The fungal cell wall has been considered as an ideal target for the development of novel antifungal agents. Several enzymes in the biosynthesis of the cell wall such as chitin and glucan synthases are unique to fungi, and thus serve as suitable targets ${ }^{20-23)}$. Various compounds affecting the chitin synthesis have been discovered ${ }^{19,24,25)}$. Among them, nikkomycins exhibit synergic effects with azole and glucan synthase inhibitors ${ }^{25)}$. In $S$. cerevisiae, chitin synthase I and III are more sensitive to nikkomycin derivatives than is chitin synthase ${ }^{1{ }^{19}}{ }^{\text {. }}$. Nikkomycin $Z$ is inhibitory specifically for chitin synthase III in $S$.

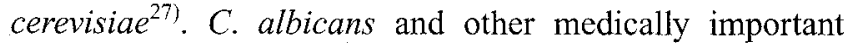
fungi are resistant to polyoxins because of their poor transport across the cell membrane ${ }^{28)}$. Thus, the potency of

Table 4. The antifungal activities of phellinsin A against various human and plant pathogens.

(MIC : $\mu \mathrm{g} / \mathrm{ml})$

\begin{tabular}{|c|l|c|c|}
\hline \multicolumn{1}{|c|}{ Pathogens } & Phellinsin A & Polyoxin D \\
\hline \multirow{5}{*}{ Human } & Candida albicans ATCC 10231 & $>100$ & $>100$ \\
\cline { 2 - 4 } & C. lusitaniae ATCC 42720 & $>100$ & $>100$ \\
\cline { 2 - 4 } & C. krusei ATCC 6258 & $>100$ & $>100$ \\
\cline { 2 - 4 } & C. tropicalis ATCC 13803 & $>100$ & $>100$ \\
\cline { 2 - 4 } & Coccidioides immitis ATCC 34020 & 100 & 100 \\
\cline { 2 - 4 } & Cryptococcus neoformans ATCC 36556 & 100 & $>100$ \\
\cline { 2 - 4 } & Aspergillus fumigatus ATCC 16424 & 50 & $>100$ \\
\cline { 2 - 4 } & Trichophyton mentagrophytes ATCC 9533 & 50 & $>100$ \\
\hline \multirow{5}{*}{ Plant } & Alternaria kikuchiana & 100 & $>100$ \\
\cline { 2 - 4 } & Botrytis cinerea & 100 & $>100$ \\
\cline { 2 - 4 } & Colletotrichum lagenarium & 12.5 & $>100$ \\
\cline { 2 - 4 } & Fusarium oxysporum & 5100 & $>100$ \\
\cline { 2 - 4 } & Pyricularia oryzae & 50 & 50 \\
\cline { 2 - 4 } & Rhizoctonia solani & & 100 \\
\hline
\end{tabular}


an inhibitor may depend on the cell wall as well as its affinity to a given enzyme.

In the course of our continuous screening to find new antifungal agents from microorganisms, we isolated a novel compound, phellinsin A, possessing a phenol and $\gamma$-lactone from Phellinus sp. PL3. Phellinsin A was shown to be as an inhibitor of chitin synthase I and II , which is responsible for the synthesis of fungal cell wall. The $\mathrm{IC}_{50}$ value of phellinsin A against chitin synthase I and II were 76 and $28 \mu \mathrm{g} / \mathrm{ml}$, respectively, which is more inhibitory than polyoxin D and chaetoatrosin A (Fig. 6). Phellinsin A did not exhibit inhibitory activity against chitin synthase III at concentrations up to $280 \mu \mathrm{g} / \mathrm{ml}$. The structure of phellinsin A is different from other chitin synthase II inhibitors previous reported such as polyoxin D from Streptomyces sp. ${ }^{19)}$, chaetoatrosin A from Chaetomium sp. ${ }^{29)}$, catechin from Taxus cuspidata ${ }^{30)}$, and ursolic acid from Crataegus pinnatifida $^{31)}$. Phellinsin $\mathrm{A}$ was active against various pathogenic fungi but it exhibited weak activity against pathogenic yeasts and Fusarium oxysporum (MIC, $\geq 100 \mu \mathrm{g} / \mathrm{ml}$ ) (Table 4). Overall, the antifungal activity of phellinsin $\mathrm{A}$ is more potent than that of polyoxin $\mathrm{D}$. Thus, phellinsin $\mathrm{A}$ is unique in that it is a potent chitin synthase I and II inhibitor with antifungal activity in vitro. Therefore, we consider that phellinsin A may be a useful lead compound for development of new antifungal agents through the regulation of chitin biosynthesis. Structural modifications of phellinsin $\mathrm{A}$ to improve its antifungal activity are now in progress.

\section{Acknowledgments}

We thank Dr. E. CABIB (NIH, U.S.A.) providing the recombinant $S$. cerevisiae. This work was supported by the grants from the Ministry of Science and Technology and the Ministry of Agriculture and Forestry in Korea.

\section{References}

1) CABib, E.; J. A. Shaw, P. C. Mol, B. Bower \& W. J. CHOI: Chitin biosynthesis and morphogenetic process. In The Mycota. Biochemistry and Molecular Biology. Vol. III. Ed. R. BRAmbl \& G. A. Marzluf, pp. 243 267, Springer-Verlag, Berlin, 1996

2) BulAWA, C. E.: $C S D 2, C S D 3$, and $C S D 4$, genes required for chitin synthesis in Saccharomyces cerevisiae: the CSD2 gene product is related to chitin synthases and to developmentally regulated proteins in Rhizobium species and Xenopus laevis. Mol. Cell. Biol. 12: 1764 1776, 1992

3) Takita, M. A. \& B. Castilho-Valavicius: Absence of cell wall chitin in Saccharomyces cerevisiae leads to resistance to Kluyveromyces lactis killer toxin. Yeast 9: $589 \sim 598,1993$
4) Bulawa, C. E. \& B. C. Osmond: Chitin synthase I and chitin synthase II are not required for chitin synthesis in vivo in Saccharomyces cerevisiae. Proc. Natl. Acad. Sci. U.S.A. 87: 7424 7428, 1990

5) Shaw, J. A.; P. C. Mol, B. Bowers, S. J. Silverman, M. M. Valdivieso, A. Duran \& E. CabiB: The function of chitin synthases 2 and 3 in the Saccharomyces cerevisiae cell cycle. J. Cell Biol. 114: 111 123, 1991

6) Cabib, E.; B. Sburlati, B. Bowers \& S. J. Silverman: Chitin synthase I, an auxiliary enzyme for chitin synthesis in Saccharomyces cerevisiae. J. Cell Biol. 108: $1665 \sim 1672,1989$

7) Cabib, E.; S. J. Silverman \& J. A. Shaw: Chitinase and chitin synthase I: counterbalancing activities in cell separation of Saccharomyces cerevisiae. J. Gen. Microbiol. 138: 97 102, 1992

8) Silverman, S. J.: Similar and different domains of chitin synthases 1 and 2 of Saccharomyces cerevisiae: two isozyme with distinct functions. Yeast 5: 459 467, 1989

9) Silverman, S. J.; A. Sburlati, M. Slater \& E. Cabib: Chitin synthase 2 is essential function and cell division in Saccharomyces cerevisiae. Proc. Natl. Acad. Sci. U.S.A. 85: 4735 4739, 1988

10) Sburlati, A. \& E. CABIB: Chitin synthethase 2, a presumptive participant in septum formation in Saccharomyces cerevisiae. J. Biol. Chem. 261: 15147 15152, 1986

11) Gilbertson, R. L. \& L. Ryvarden: North American Polypores. Vol. 2. pp. 541 623, Fungiflora, Oslo, Norway, 1987

12) Chог, W. J. \& E. CABIB: The use of divalent cations and $\mathrm{pH}$ for the determination of specific yeast chitin synthetases. Anal. Biochem. 219: 368 372, 1994

13) Lowry, O. H.; N. J. Rosebrough, A. L. Farr \& R. J. RANDALL: Protein measurement with the folin phenol reagent. J. Biol. Chem. 193: 265 275, 1951

14) Stalpers, J. A.: Studies in Mycology. No 16; Identification of wood-inhibiting fungi in pure culture. $p$. 248, Centraalbureau voor Schimmelcultures, Baarn, Netherlands, 1978

15) Ryvarden, L. \& R. L. Gilbertson: European Polypores. Vol. 1 2. p. 743, Fungiflora, Oslo, Norway, 1993

16) Larsen, M. J. \& L. A. Cobb-Poulle: Synopsis Fungorum 3: Phellinus (Hymenochaetaecae)-A survey of the world taxa. p. 206, Fungiflora, Oslo, Norway, 1990

17) Gilbertson, R. L. \& L. Ryvarden: North American Polypores. Vol. $1 \sim 2$. p. 885, Fungiflora, Oslo, Norway, 1987

18) DAI, Y. C. \& M. Q. XU: Studies on the medicinal polypore, Phellinus baumil, and its kin, P. linteus. Mycotaxon 62: 191 200, 1998

19) CABIB, E.: Differential inhibition of chitin synthases 1 and 2 from Saccharomyces cerevisiae by polyoxin D and nikkomycin Z. Antimicrob. Agents Chemother. 35: $170 \sim 173,1991$

20) Georgopapadakou, N. H.: Antifungals targeted to the cell wall. Exp. Opin. Invest. Drugs. 6: 147 150, 1997

21) DenNing, D. W.: Echinocandins and pneumocandins- a new antifungal class with a novel mode of action. J. Antimicrob. Chemother. 40:611 614, 1997

22) Sakurai, T.; N. Cheepthan, T. Mikawa, A. Yokota \& F. TOMITA: A novel screen for the detection of chitin acting antifungal compounds. J. Antibiotics 52: 508 511, 1999 
23) Naowarat; C.; T. Higashiyama, N. Phay \& F. Tomita: Rapid and unique screening system for the discovery of new antifungal antibiotics against chitin synthesis in fungal cell walls. Thai J. Biotechnol. 1(1): 31 36, 1999

24) Naowarat, C.; N. Phay, T. Higashiyama, E. Fukushi, H. Matsuura, T. Mikawa, A. YoKota, A. Ichihara \& F. TOMITA: Studies on an antifungi antibiotic from Ellisiodothis inguinans L1588-A8. Thai J. Biotechnol. 1(1): 37 45, 1999

25) Pfefferle, W.; H. AnKe \& M. Bross: Inhibition of solubilized chitin synthase by chlorinated aromatic compounds isolated from mushroom cultures. Agric. Biol. Chem. 54(6): 1381 1384, 1990

26) Hector, R. F. \& P. C. Braun: Synergic action of nikkomycin $X$ and $Z$ with papulacandin $B$ on whole cells and regenerating protoplasts of Candida albicans. Antimicrob. Agents Chemother. 29: 389 394, 1986

27) Gaughram, J. P; M. H. Lai, D. R. Kirsch \& S. J. SILVERMAN: Nikkomycin $Z$ is a specific inhibitor of
Saccharomyces cerevisiae chitin synthase isozyme chs 3 in vitro and in vivo. J. Bacteriol. 176: 5857 5860, 1994

28) CABIB, E.; R. Roberts \& B. Bowers: Synthesis of the yeast cell wall and its regulation. Ann. Rev. Biochem. 51: 763 793, 1982

29) Hwang, E. I.; B. S. Yun, Y. K. Kim, B. M. Kwon, H. G. KIM, H. B. LeE, K. S. BAE \& S. U. KIM: Chaetoatrosin A, a novel chitin synthase II inhibitor produced by Chaetomium atrobrunneum F449. J. Antibiotics 53: 248 255, 2000

30) Kim, S. U.; E. I. Hwang, J. Y. Nam, K. H. SON, S. H. BOK, H. E. KIM \& B. M. KwON: Inhibition of chitin synthase II by catechins from stem bark of Taxus cuspidata. Planta Medica 65: 97 98, 1999

31) Jeong, T. S.; E. I. Hwang, H. B. Lee, E. S. Lee, Y. K. Kim, B. S. MrN, K. H. BaE, S. H. BoK \& S. U. Kim: Chitin stnthase II Inhibitory activity of ursolic acid, isolated from Crataegus pinnatifida. Planta Medica 65: $261 \sim 263,1999$ 